Volume $46 \quad$ No. $1 \quad$ Spring 2012

\title{
LONG RUN SUSTAINABILITY OF SARAWAK - WEST KALIMANTAN CROSS-BORDER TRADE FLOWS
}

\author{
Nurul Bariyah \\ Universitas Tanjungpura, Indonesia \\ Evan Lau* \\ Universiti Malaysia Sarawak, Malaysia \\ Shazali Abu Mansor \\ Universiti Malaysia Sarawak, Malaysia
}

\begin{abstract}
This paper is concerned with the time series behaviour of the cross border trade flows between Sarawak (East Malaysia) - West Kalimantan (Indonesia) conducted through regional port of Tebedu custom district with the main focus on the long run sustainability of Sarawak trade deficits. Cross border trade activity has gain much attention due to the dynamic linkages of this unique regional economic activity on industry, investment and employment, yet the study on long-run relationships of cross border trade flows have been largely overlooked. By employing the three stages of modern time series econometric technique, the research found significant long run cointegration relationship for the bilateral trade flows as well as support for the strong form of sustainability condition, suggesting that Sarawak-West Kalimantan bilateral trade is on the sustainable path in governing their trade flows performance. This suggests that the macroeconomic policies of Sarawak and West Kalimantan have been effective in bringing exports and imports into a long run equilibrium.
\end{abstract}

JEL classification: F10, F40, C32

Keywords: Bilateral Trade Sustainability, Sarawak, West Kalimantan

Corresponding Author's E -mail Address: Iphevan@feb.unimas.my or ygwiex@yahoo.com

\section{INTRODUCTION}

Separated by $? 800 \mathrm{~km}$ length of borderline, West Kalimantan (Indonesia) and Sarawak (East Malaysia) together form one large economy in Borneo Island -- the third largest island in the world -- with total population of 6.5 million $(36 \%$ of Borneo total population) and total GDP of 11.2 billion US\$. This border pair connected with each other by at least 50 pathways $^{1}$ that have been used from generation to generation for different purposes such as leisure, visiting relatives/friends, participating in religious festival and games or actively involve in economic activities that generate significant income $^{2}$. Among those, Tebedu (Malaysia border district) -Entikong (Indonesia border district) crossing is the only official international gate where formal export and import between the two takes place.

Trade along the border of Sarawak - West Kalimantan has a long history with the first government intervention recorded over 40 years ago $^{3}$. Geography, economic growth, economic integration, and financial crisis that lead to the depreciation of Rupiah (Indonesian currency) have all contributed to the increase volumes of trade between 